УДК 547.458 .83

\title{
СИНТЕЗ И ИССЛЕДОВАНИЕ БИОЛОГИЧЕСКОЙ АКТИВНОСТИ СУЛЬФАМИНОВЫХ ПРОИЗВОДНЫХ ПОЛИСАХАРИДОВ
}

\author{
() О.Р. Ахмедов", Ш.А. Шомуротов, Г.Г. Рахманова, А.С. Тураев \\ Институт биоорганической химии АН Республики Узбекистан, \\ ул. М. Улугбека, 83, Ташкент 100125 (Узбекистан), e-mail: ibchem@uzsci.net
}

\begin{abstract}
Взаимодействием сульфаминовой кислоты с диальдегид производными полисахаридов получены новые водорастворимые производные крахмала, пектина и $\mathrm{Na}$-КМЦ, содержащие сульфаминовые группы. Структура и состав полученных соединений изучена методом ИК-спектроскопии, элементных (азот, сера) и рентгеноструктурных анализов.

Изменяя концентрацию сульфаминовой кислоты в отношении диальдегид производных полисахаридов, получили сульфаминовые производные крахмала, пектина и Na-КМЦ с различным содержанием сульфаминовых групп. Найдено оптимальное соотношение, равное - $\mathrm{CHO}: \mathrm{NH}_{2} \mathrm{SO}_{3} \mathrm{H}=1,0: 2,5$. и Na-КМЦ

Исследована скорость взаимодействия сульфаминовой кислоты с диальдегид производными крахмала, пектина

Приведены результаты исследований антимикробного и противогрибкового действия натриевых солей сульфаминовых производных крахмала, пектина и Na-КМЦ. Биологическая активность полученных соединений изучена при различных концентрациях 10, 25, 50 мг/мл диско-диффузионным методом в отношении грамположительных и грамотрицательных бактерий, а также грибах. Определено, что синтезированные соединения не проявляют противогрибкового действия в отношении Candida albicans, но обладают антимикробной активностью в отношении Staphylococcus aureus, Staphylococcus epidermidis, Escherichia coli, Proteus vulgaris, Streptococcus faecalis, Streptococcus pyogenes и Streptococcus faecalis при концентрации 50 мг/мл.

Показана зависимость антимикробного действия натриевых солей сульфаминовых производных крахмала, пектина и Na-КМЦ от концентрации.

Установлена прямая зависимость антимикробной активности препаратов от количественного содержания сульфаминовых групп в полисахаридах. Приведены результаты исследований острой токсичности сульфаминовых производных полисахаридов, по результатам которых их можно отнести к V классу - практически нетоксичных веществ.

Ключевые слова: крахмал, пектин, Na-КМЦ, периодатное окисление, сульфаминовая кислота, острая токсичность, антимикробная активность.
\end{abstract}

\section{Введение}

Получение новых производных полисахаридов, обладающих биологической активностью, остается одной из основных задач химии, фармацевтики и медицины. В плане синтеза новых биологически активных веществ особое место занимают химически модифицированные полисахариды, содержащие альдегидные группы $[1,2]$. Известно, что наличие в полисахаридах альдегидных групп, способных в мягких условиях образовать азометиновую связь с первичными аминогруппами лекарственных соединений, позволило

Ахмедов Олий Равщанович - младший научный сотрудник лаборатории химии полисахаридов, e-mail: oliy86@bk.ru, ibchem@uzsci.net

Шомуротов Шавкат Абдуганиевич - кандидат химических наук, старший научный сотрудник лаборатории химии полисахаридов, e-mail:shsha@mail.ru

Рахманова Гульнора Гулямовна - младший научный сотрудник лаборатории фармакологии, e-mail: gogosha-r@mail.ru

Тураев Аббасхан Сабирханович - доктор химических наук, ведущий научный сотрудник лаборатории химии полисахаридов, e-mail: ibchem@uzsci.net получить полимерные формы противотуберкулезных, антимикробных и противоопухолевых препаратов. Данные лекарственные препараты, в свою очередь, обладают улучшенными фармакологическими и физико-химическими свойствами (водорастворимость, малая токсичность, пролонгированное действие, адресная доставка препарата) [3-6].

Представляют интерес исследования, в которых посредством диальдегид полисахаридов удалось ввести гидрофильные группы в макромолекулу биополимеров, что придало полисахаридам раство-

\footnotetext{
* Автор, с которым следует вести переписку.
} 
римость и биологическую активность [7-9]. Также диальдегид полисахариды находят широкое применение для получения пленочных материалов [10, 11].

В данной работе для получения новых биологически активных веществ нами использованы диальдегиды полисахаридов, полученные путем избирательного окисления периодатом натрия. В качестве исходных полисахаридов были использованы: кукурузный крахмал очищенный (фирмы Sigma-Aldrich); цитрусовый пектин очищенный, $\mathrm{MM}=162000$, содержание $-\mathrm{OCH}_{3}$ групп = 7,6\%; Na-КМЦ очищенная, СП = $400, \gamma=85 \pm 5$. В качестве нуклеофильного реагента использована сульфаминовая кислота $\left(\mathrm{NH}_{2} \mathrm{SO}_{3} \mathrm{H}\right)$, содержащая первичную аминогруппу.

\section{Экспериментальная часть}

Периодатное окисление полисахаридов. В стеклянном стакане 3 г крахмала залили 100 мл дистиллированной воды и оставили на 1 ч, затем добавили 100 мл ацетатного буферного раствора с рН 4,3 и 0,2 н раствора $\mathrm{NaIO}_{4}$ при мольном соотношении крахмал : $\mathrm{NaIO}_{4}=1: 1,5$, процесс окисления продолжался 8-10 ч, при температуре $25^{\circ} \mathrm{C}$ [12]. По окончании реакции периодатного окисления, модифицированный крахмал отделили от раствора и промыли дистиллированной водой до отрицательной реакции на ионы $\mathrm{IO}_{4}{ }^{-}$и $\mathrm{IO}_{3}{ }^{-}$ (контроль по реакции с раствором азотнокислого серебра). Периодатное окисление пектина и Na-КМЦ проводили по методикам $[12,13]$, при постоянном $\mathrm{pH} 4,3$, с помощью 0,25 н раствора $\mathrm{NaIO}_{4}$ при мольном соотношении пектина, $\mathrm{Na}-\mathrm{KMЦ} \mathrm{:} \mathrm{NaIO}_{4}=1: 1,0$ и продолжительности времени реакций окисления 2,5-3 ч. Полученные продукты реакций осаждали ацетоном. Образовавшиеся осадки промывали 75\%-ным этанолом. Полученные диальдегид производные полисахаридов сушили в темноте под вакуумом над $\mathrm{P}_{2} \mathrm{O}_{5}$.

Содержание альдегидных групп определили йодометрическим методом. Полученные диальдегид полисахариды имели следующую степень окисления (СО): диальдегидкрахмал (ДАК) 50-56 моль\%, диальдегидпектин (ДАП) 35-38 моль\% и диальдегид Na-КМЦ (ДАКМЦ) 26-28 моль\%.

Получение натриевьх солей сульфаминовых производных полисахаридов. К растворам, содержащим от 0,015 до 0,04 моль сульфаминовой кислоты, добавляли по 0,01 моль окисленных полисахаридов, из расчета 1 моль диальдегидных звеньев на 1,5-4 моль $\mathrm{NH}_{2} \mathrm{SO}_{3} \mathrm{H}$ и перемешивали при температуре $25^{\circ} \mathrm{C}$ в течение 120 мин. Затем в реакционные смеси добавляли 10\% раствор $\mathrm{Na}_{2} \mathrm{CO}_{3}$ и доводили рН среды до 8,0-8,5. Образовавшуюся азометиновую связь $(-\mathrm{C}=\mathrm{N}-)$ восстанавливали с помощью боргидрида натрия. Реакция восстановления $-\mathrm{C}=\mathrm{N}$ - связи продолжалась 3 ч, боргидрида натрия брали в двухкратном избытке по отношению к количеству альдегидных групп полисахаридов. Продукты реакции осаждали и промывали ацетоном. Образовавшиеся осадки растворяли в воде, очищали от примесей методом диализа в течение 18 ч и высушивали лиофилизацией.

ИК-спектры полученных соединений записаны на Фурье ИК-спектрометре Vector-22 в области длин волн 400-4000 см ${ }^{-1}$ в таблетках $\mathrm{KBr}$ (3 мг образца / 300 мг KBr). Физическую структуру исследовали на порошковом дифрактометре XRD-6100 (Shimadzu, Япония).

Состав полученных натриевых солей сульфаминовых производных крахмала, пектина и Na-КМЦ изучали по содержанию серы и азота. Содержание серы определяли на элементном анализаторе ЕА 1108 фирмы Карло Эрба (Италия), количество азота - по методу Кьельдаля [14]. Степень замещения сульфаминовых производных полисахаридов определяли по содержанию азота [15].

Антимикробную активность сульфаминовых производных изучали в условиях in vitro дискодиффузионным методом [16], токсичность исследована по методу К.В. Прозорского.

Натриевые соли сульфаминовых производных полисахаридов получены по следующей схеме:

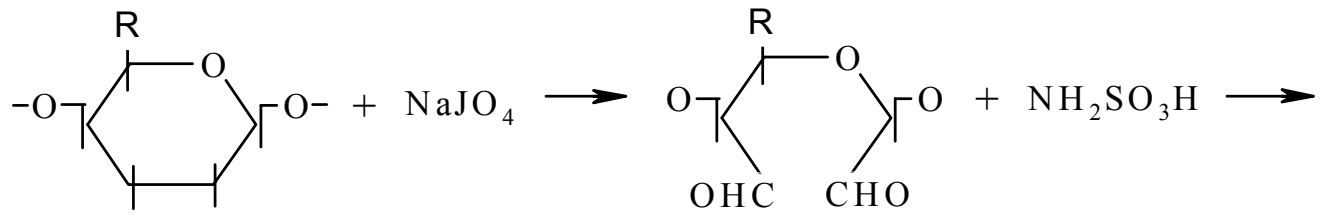




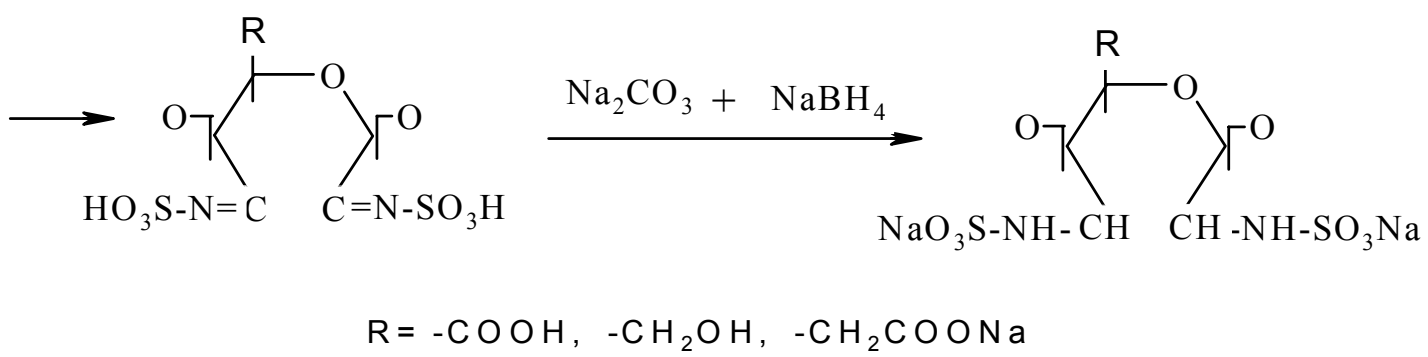

\section{Обсуждение результатов}

Из полученных данных (табл. 1) следует, что с увеличением степени окисления полисахаридов и соотношения $\mathrm{NH}_{2} \mathrm{SO}_{3} \mathrm{H}$ повышается степень замещения (C3) конечных продуктов. Повышение концентрации сульфаминовой кислоты в реакционной среде до 2,5 моль приводит к увеличению содержания сульфаминовых групп в полисахариде. Дальнейшее повышение концентрации $\mathrm{NH}_{2} \mathrm{SO}_{3} \mathrm{H}$ незначительно увеличивает количество сульфаминовых групп в конечных продуктах.

По результатам ИК-спектра и данным таблицы 1 можно отметить, что не все альдегидные группы взаимодействуют с сульфаминовой кислотой, даже при соотношении $-\mathrm{CHO}: \mathrm{NH}_{2} \mathrm{SO}_{3} \mathrm{H}=1,0: 4,0$. Повидимому, это связано с образованием электростатического эффекта отталкивания между сульфаминовой кислотой и уже содержащимися в полисахаридах сульфаминовыми группами, что не позволяет полностью прореагировать $\mathrm{NH}_{2} \mathrm{SO}_{3} \mathrm{H}$ с альдегидными группами полисахаридов. Альдегидные группы, не вступившие в реакцию, находятся в свободном состоянии (поглощение в области 1692-1725 см${ }^{-1}$ ), после реакции восстановления поглощение в области 1692-1725 см-1 исчезает.

Взаимодействия сульфаминовой кислоты с диальдегид производными крахмала, пектина и Na-КМЦ протекают интенсивно в течение первых 30 мин (рис. 1), затем скорость реакции начинает постепенно снижаться. Наибольшее содержание сульфаминовых групп в крахмале составляет 42 моль\% при продолжительности времени реакции 80 мин, в пектине 29 моль\% - 60 мин и в Nа-КМЦ 23 моль\% - 45 мин. Дальнейшее увеличение продолжительности времени реакции (до 120 мин) не приводит к повышению содержания сульфаминовых групп в конечных продуктах.

В ИК-спектрах полученных сульфаминовых производных крахмала, пектина и Na-КМЦ присутствуют полосы поглощения в области 3310-3450 см${ }^{-1}(-\mathrm{OH}), 1555-1600 \mathrm{~cm}^{-1}(-\mathrm{NH}-), 1230-1250 \mathrm{~cm}^{-1}\left(\mathrm{SO}_{2}\right)$, $805-823 \mathrm{~cm}^{-1}$ (SO).

Таблица 1. Состав продуктов взаимодействия ДАК, ДАП и ДАКМЦ с сульфаминовой кислотой (время 120 мин, $\left.25^{\circ} \mathrm{C}\right)$

\begin{tabular}{|c|c|c|c|c|c|}
\hline $\begin{array}{c}\text { № } \\
\text { синтеза }\end{array}$ & $\begin{array}{c}\text { Степень окисления (СО) } \\
\text { полисахаридов, моль\% }\end{array}$ & $\begin{array}{c}\text { Соотношение } \\
-\mathrm{CHO} \mathrm{:} \mathrm{NH}_{2} \mathrm{SO}_{3} \mathrm{H}, \text { моль }\end{array}$ & $\begin{array}{c}\text { Содержание } \\
\text { азота, \% }\end{array}$ & $\begin{array}{l}\text { Содержание } \\
\text { серы, \% }\end{array}$ & $\begin{array}{l}\text { Степень замеще- } \\
\text { ния (С3) моль\% }\end{array}$ \\
\hline \multicolumn{6}{|c|}{ ДАК } \\
\hline 1 & 50 & $1,0: 2,0$ & 4,4 & 4,9 & 30 \\
\hline 2 & 51 & $1,0: 2,5$ & 5,1 & 5,6 & 35 \\
\hline 3 & 50 & $1,0: 3,0$ & 5,4 & 5,9 & 37 \\
\hline 4 & 56 & $1,0: 2,5$ & 6,1 & 6,8 & 42 \\
\hline 5 & 56 & $1,0: 4,0$ & 6,3 & 7,2 & 44 \\
\hline \multicolumn{6}{|c|}{ ДАП } \\
\hline 6 & 35 & $1,0: 2,0$ & 3,2 & 3,6 & 23 \\
\hline 7 & 35 & $1,0: 2,5$ & 3,9 & 4,3 & 28 \\
\hline 8 & 35 & $1,0: 3,0$ & 4,2 & 4,7 & 30 \\
\hline 9 & 38 & $1,0: 2,5$ & 4,1 & 4,5 & 29 \\
\hline 10 & 38 & $1,0: 4,0$ & 4,4 & 4,8 & 31 \\
\hline \multicolumn{6}{|c|}{ ДАКМЦ } \\
\hline 11 & 26 & $1,0: 1,5$ & 1,3 & 1,8 & 14 \\
\hline 12 & 27 & $1,0: 2,0$ & 1,7 & 2,3 & 18 \\
\hline 13 & 27 & $1,0: 2,5$ & 2,1 & 2,9 & 23 \\
\hline 14 & 28 & $1,0: 3,0$ & 2,1 & 2,9 & 23 \\
\hline
\end{tabular}




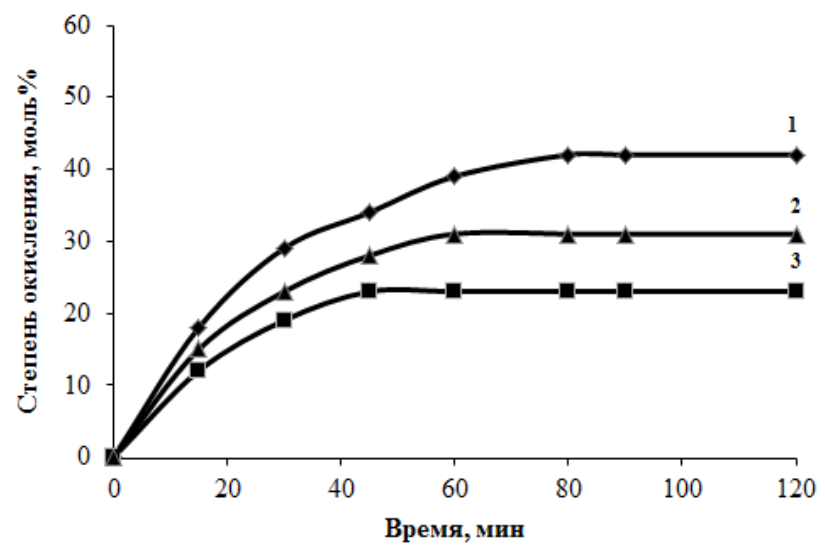

Рис. 1. Скорость взаимодействия сульфаминовой кислоты с ДАК - $\mathrm{CO}=56$ моль \% (1), ДАП - СО = 38 моль \% (2), ДАКМЦ - $\mathrm{CO}=28$ моль $\%$ (3) при соотношении - $\mathrm{CHO}: \mathrm{NH}_{2} \mathrm{SO}_{3} \mathrm{H}=1,0: 2,5$, $25^{\circ} \mathrm{C}$

Проведенные исследования по изучению физической структуры сульфаминовых производных крахмала, пектина и $\mathrm{Na-КМЦ} \mathrm{(аморфное} \mathrm{или} \mathrm{кристаллическое} \mathrm{состояние)} \mathrm{показали,} \mathrm{что} \mathrm{данные} \mathrm{соедине-}$ ния являются аморфными веществами (рис. 2). Аморфизация крахмала, пектина и a-КМЦ происходит в результате уменьшения количества $-\mathrm{OH}$ групп и разрушения упорядоченных упаковок полисахаридов в процессе периодатного окисления [17, 18].

С целью изучения биологической активности полученных новых производных полисахаридов были проведены исследования на грамположительных и грамотрицательных бактериях, а также грибах (Candida albicans), при концентрации соединений 10, 25, 50 мг/мл, диско-диффузионным методом.

Антимикробная активность натриевых солей сульфаминовых производных полисахаридов оценивалась по диаметру зон задержки роста бактерий и грибов: «-»- зона задержки роста отсутствует. Диаметры зон задержки роста меньше 10 мм - отсутствие антибактериальной активности; 10-15 мм - слабая активность; 15-20 мм - умеренно выраженная активность; свыше 20 мм - выраженная.
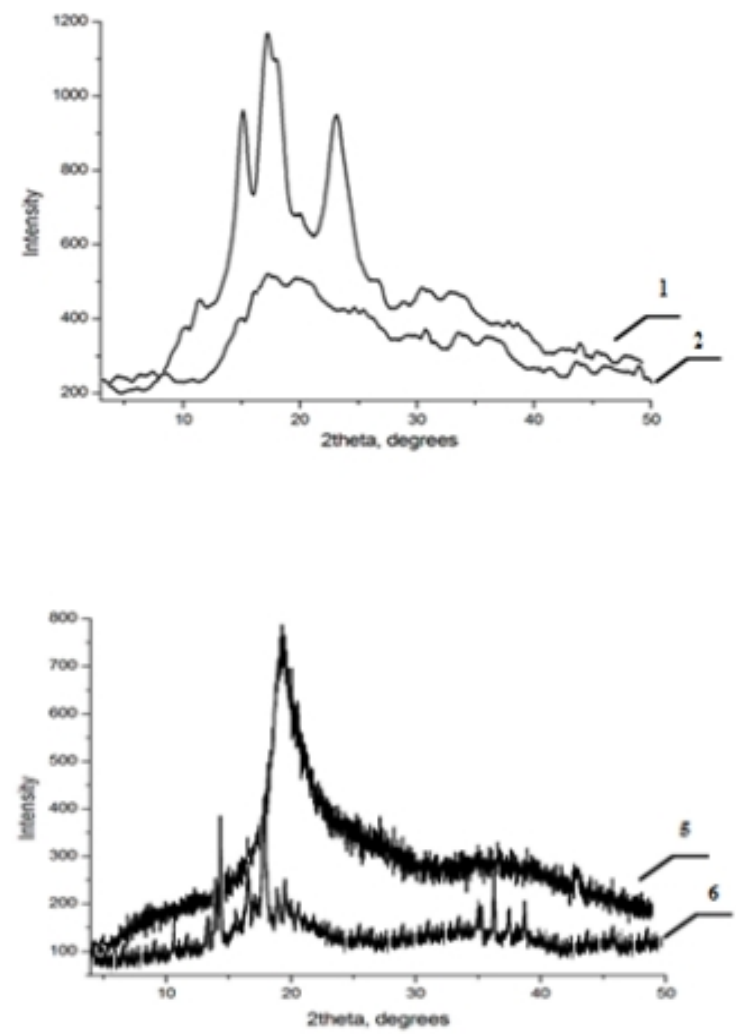

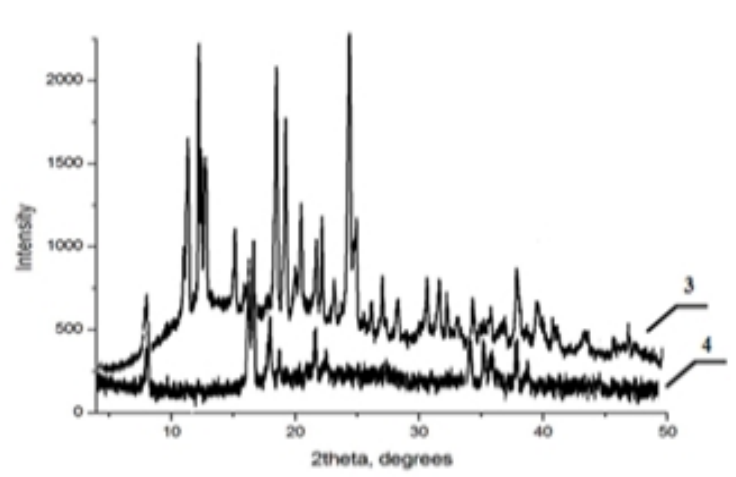

Рис. 2. Рентгенограммы крахмала, пектина, Na-КМЦ $(1,3,5)$ и их сульфаминовых производных $(2,4,6)$ 
Как следует из таблиц 2, 3, 4, антимикробная активность зависит от концентрации сульфаминовых производных крахмала, пектина и Na-КМЦ. При концентрации 10 мг/мл полученные соединения не проявляют антимикробного действия в отношении большинства бактерий, увеличение их концентрации до 25 и 50 мг/мл приводит к повышению активности и расширению спектра антимикробного действия. Так, при концентрации 50 мг/мл синтезированные соединения проявляют антимикробное действие в отношении Staphylococcus aureus, Staphylococcus epidermidis, Escherichia coli, Proteus vulgaris, Streptococcus faecalis, Streptococcus pyogenes u Streptococcus faecalis. В отношении Candida albicans сульфаминовые производные крахмала, пектина и Na-КМЦ не показали активность. Таким образом, можно отметить, что концентрация, при которой сульфаминовые производные крахмала, пектина и Na-КМЦ начинают проявлять более выраженное действие в отношении грамотрицательных и грамположительных бактерий, равна 50 мг/мл.

В целях определения зависимости антимикробного действия от количественного содержания сульфаминовых групп были проведены исследования, в которых использовались образцы с меньшей С3 (табл. 5).

Полученные результаты позволяют сделать вывод, что антимикробная активность зависит от количественного содержания сульфаминовых групп в полисахаридах. С уменьшением количества сульфаминовых групп антимикробное действие начинает понижаться.

Результаты исследования острой токсичности показали, что для сульфаминовых производных крахмала $\mathrm{LD}_{50}$ составляет 8000 мг/кг, пектина - 6100 мг/кг, Na-КМЦ - 5130 мг/кг, что дает основание отнести их к V классу - практически нетоксичных веществ.

Таблица 2. Чувствительность микробов к сульфаминовым производным крахмала со С3= 42 моль\%

\begin{tabular}{c|l|c|c|c}
\hline \multirow{2}{*}{$№$} & \multicolumn{1}{|c}{ Микроорганизмы } & \multicolumn{3}{|c}{ Концентрация, мг/мл } \\
\cline { 3 - 5 } & \multicolumn{2}{|c}{10} & 25 & 50 \\
\hline 1 & Staphylococcus aureus & $9,0 \pm 0,1$ & $11,0 \pm 0,2$ & $15,0 \pm 0,3$ \\
2 & Staphylococcus epidermidis & $7,0 \pm 0,2$ & $9,0 \pm 0,1$ & $12,0 \pm 0,1$ \\
3 & Klebsiella & $5,0 \pm 0,1$ & $7,0 \pm 0,2$ & $9,0 \pm 0,1$ \\
4 & Escherichia coli & $7,0 \pm 0,2$ & $10,0 \pm 0,2$ & $13,0 \pm 0,1$ \\
5 & Proteus vulgaris & $5,0 \pm 0,1$ & $9,0 \pm 0,2$ & $13,0 \pm 0,2$ \\
6 & Candida albicans & - & - & - \\
7 & Streptococcus pyogenes & $5,0 \pm 0,2$ & $8,0 \pm 0,2$ & $11,0 \pm 0,1$ \\
8 & Streptococcus faecalis & $5,0 \pm 0,1$ & $7,0 \pm 0,2$ & $11,0 \pm 0,3$ \\
9 & Pseudomonas aeruginosa & $7,0 \pm 0,2$ & $10,0 \pm 0,2$ & $13,0 \pm 0,3$ \\
\hline
\end{tabular}

Таблица 3. Чувствительность микробов к сульфаминовым производным пектина со С3 = 29 моль\%

\begin{tabular}{c|l|c|c|c}
\hline \multirow{2}{*}{ № } & \multicolumn{1}{|c|}{ Микроорганизмы } & \multicolumn{3}{|c}{ Концентрация, мг/мл } \\
\cline { 2 - 4 } & \multicolumn{1}{|c}{10} & 25 & 50 \\
\hline 1 & Staphylococcus aureus & $7,0 \pm 0,2$ & $10,0 \pm 0,2$ & $12,0 \pm 0,2$ \\
2 & Staphylococcus epidermidis & $5,0 \pm 0,1$ & $8,0 \pm 0,1$ & $12,0 \pm 0,1$ \\
3 & Klebsiella & - & - & - \\
4 & Escherichia coli & $5,0 \pm 0,2$ & $9,0 \pm 0,2$ & $11,0 \pm 0,2$ \\
5 & Proteus vulgaris & $10,0 \pm 0,2$ & $16,0 \pm 0,1$ & $20,0 \pm 0,2$ \\
6 & Candida albicans & - & - & - \\
7 & Streptococcus pyogenes & $10,0 \pm 0,1$ & $12,0 \pm 0,1$ & $16,0 \pm 0,1$ \\
8 & Streptococcus faecalis & $8,0 \pm 0,1$ & $10,0 \pm 0,2$ & $12,0 \pm 0,2$ \\
9 & Pseudomonas aeruginosa & $7,0 \pm 0,2$ & $7,0 \pm 0,2$ & $10,0 \pm 0,2$ \\
\hline
\end{tabular}

Таблица 4. Чувствительность микробов к сульфаминовым производным Na-КМЦ со С3 = 23 моль\%

\begin{tabular}{c|l|c|c|c}
\hline \multirow{2}{*}{ № } & \multicolumn{1}{|c|}{ Микроорганизмы } & \multicolumn{3}{|c}{ Концентрация, мг/мЛ } \\
\cline { 3 - 4 } & & 10 & 25 & 50 \\
\hline 1 & Staphylococcus aureus & $9,0 \pm 0,1$ & $10,0 \pm 0,2$ & $13,0 \pm 0,2$ \\
2 & Staphylococcus epidermidis & $7,0 \pm 0,1$ & $10,0 \pm 0,1$ & $12,0 \pm 0,1$ \\
3 & Klebsiella & $10,0 \pm 0,1$ & $12,0 \pm 0,1$ & $15,0 \pm 0,1$ \\
4 & Escherichia coli & $7,0 \pm 0,1$ & $9,0 \pm 0,1$ & $12,0 \pm 0,1$ \\
5 & Proteus vulgaris & $10,0 \pm 0,2$ & $13,0 \pm 0,2$ & $16,0 \pm 0,1$ \\
6 & Candida albicans & - & - & - \\
7 & Streptococcus pyogenes & $9,0 \pm 0,1$ & $12,0 \pm 0,1$ & $15,0 \pm 0,1$ \\
8 & Streptococcus faecalis & $7,0 \pm 0,1$ & $7,0 \pm 0,1$ & $12,0 \pm 0,2$ \\
9 & Pseudomonas aeruginosa & $5,0 \pm 0,1$ & $8,0 \pm 0,2$ & $10,0 \pm 0,2$ \\
\hline
\end{tabular}


Таблица 5. Чувствительность микробов к сульфаминовым производным І-крахмала (С3 = 35 моль\%), II-пектина (С3 = 23моль\%), III-Na-КМЦ (С3 = 18 моль\%), при концентрации 50 мг/мл

\begin{tabular}{c|l|c|c|c}
\hline № & \multicolumn{1}{|c|}{ Микроорганизмы } & I & II & III \\
\hline 1 & Staphylococcus aureus & $12,0 \pm 0,1$ & $11,0 \pm 0,2$ & $12,0 \pm 0,2$ \\
2 & Staphylococcus epidermidis & $11,0 \pm 0,1$ & $10,0 \pm 0,1$ & $10,0 \pm 0,1$ \\
3 & Klebsiella & $7,0 \pm 0,2$ & - & $13,0 \pm 0,1$ \\
4 & Escherichia coli & $12,0 \pm 0,1$ & $10,0 \pm 0,2$ & $11,0 \pm 0,1$ \\
5 & Proteus vulgaris & $11,0 \pm 0,2$ & $18,0 \pm 0,2$ & $13,0 \pm 0,1$ \\
6 & Candida albicans & - & - & - \\
7 & Streptococcus pyogenes & $10,0 \pm 0,1$ & $15,0 \pm 0,1$ & $12,0 \pm 0,1$ \\
8 & Streptococcus faecalis & $9,0 \pm 0,1$ & $10,0 \pm 0,2$ & $10,0 \pm 0,2$ \\
9 & Pseudomonas aeruginosa & $10,0 \pm 0,2$ & $10,0 \pm 0,1$ & $9,0 \pm 0,1$ \\
\hline
\end{tabular}

\section{Выводы}

1. На основе диальдегид полисахаридов получены новые водорастворимые производные крахмала, пектина и Na-КМЦ, содержащие сульфаминовые группы. Структура и состав полученных соединений изучены методом ИК-спектроскопии, элементных (азот, сера) и рентгеноструктурных анализов.

2. Результаты исследования биологической активности сульфаминовых производных крахмала, пектина и Nа-КМЦ показали, что данные соединения обладают антимикробной активностью в отношении грамотрицательных и грамположительных бактерий. Выявлено, что антимикробная активность сульфаминовых производных полисахаридов зависит от их концентрации и количественного содержания сульфаминовых групп.

3. Установлено, что сульфаминовые производные крахмала, пектина и Na-КМЦ относятся к V классу - практически нетоксичных веществ.

\section{Список литературы}

1. Дятлов В.А., Круппа И.С., Мамаева С.А., Кутергина И.Ю., Гумникова В.И., Гребенова Т.А., Киреев В.В. Изменение молекулярно-массового распределения и фракционной однородности полисахаридов при их периодатном окислении // Химия природных соединений. 2014. №6. С. 845-849.

2. Х Хомяков К.П., Пенежник М.А., Вирник А.Д., Роговин З.А. Синтез диальдегид и дикарбоксилдекстрана // Высокомолекулярные соединения. 1965. Т. 7, №6. С. 1030-1034.

3. Снежко В.А., Комар В.П., Хомяков К.П., Вирник А.Д., Жбанков Р.Г., Розенберг Г.Я., Роговин 3.А. Синтез водорастворимых производных декстрана, содержащих химически присоединенные антибиотики // Высокомолекулярные соединения. 1974. Т. 16 А, №10. С. 2233-2238.

4. Шомуратов Ш.А., Муродов Э.А., Тураев А.С. Синтез и исследование комбинированного противотуберкулезного препарата на основе карбоксиметилцеллюлозы // Химия растительного сырья. 2006. №2. С. $25-28$.

5. Хомяков К.П., Вирник А.Д., Ушаков С.Н., Роговин З.А. Синтез полимерных лекарственных соединений на основе производных декстрана // Высокомолекулярные соединения. 1965. Т. 7, №6. С. 1035-1039.

6. Тевяшова А.Н., Олсуфьева Е.Н., Преображенская М.Н., Клёсов А.А., Зомер Е., Плат Д. Новые конъюгаты противоопухолевого антибиотика доксорубицина с водорастворимым галактоманнаном: синтез и биологическая активность // Биоорганическая химия. 2007. Т. 33, №1. С. 148-155.

7. Liu K., Xu Y., Lin X., Chen L., Huang L., Cao Sh., Li J. Synergistic effects of guanidine-grafted CMC on enhancing antimicrobial activity and dry strength of paper // Carbohydrate Polymers. 2014. Vol. 110. Pp. 382-387.

8. Ахмедов О.Р., Шомуротов Ш.А., Тураев А.С. Изучение химического взаимодействия модифицированных полисахаридов с гуанидином // Современные актуальные проблемы естественных наук : материалы Международной научно-практической интернет-конференции. Актобе, Казахстан. 2014. Т. 1. С. 98-101.

9. Патент № 2435785 (РФ). Модифицированная целлюлоза, обладающая биоцидными свойствами и способ ее получения / М.Ю. Исрафилович, С.Ю. Хаширова, Э.Б. Мусаева, М.Х. Лигидов, С.Н. Александрович, 3.А. Тлупова / 2011.

10. Guo J., Li X., Mu Ch., Zhang H, Qi P., Li D. Freezing-thawing effects on the properties of dialdehyde carboxymethyl cellulose crosslinked gelatin-MMT composite films // Food Hydrocolloids. 2013. Vol. 33. Pp. 273-279.

11. Ge L., Li X., Zhang R., Yang T., Ye X., Li D., Mu Ch. Development and characterization of dialdehyde xanthan gum crosslinked gelatin based edible films incorporated with amino-functionalized montmorillonite // Food Hydrocolloids. 2015. Vol. 51. Pp. 129-135.

12. Ахмедов О.Р., Шомуротов Ш.А., Тураев А.С. Особенности синтеза диальдегид производных полисахаридов // Узбекский химический журнал. 2013. №1. С. 30-33.

13. Наджимутдинов Ш., Сарымсаков А.А., Усманов Х.У. Исследование некоторых закономерностей синтеза диальдегидов целлюлозы и ее эфиров // Cellulose chemistry and technology. 1981. Т. 15, №16. С. 613-628. 
14. Цитович И.К. Курс аналитической химии. М., 1977. С. 346.

15. Ding W., Zhao P., Li R. Removal of Zn (II) ions by dialdehyde 8-aminoquinoline starch from aqueous solution // Carbohydrate Polymers. 2011. Vol. 83. Pp. 802-807.

16. Воробьев А.А., Кривошеин А.И., Широбоков В.П. Медицинская и санитарная микробиология. М., 2003. С. 44.

17. Yu J., Chang R., Ma X. The preparation and properties of dialdehyde starch and thermoplastic dialdehyde starch // Carbohydrate Polymers. 2010. Vol. 79. Pp. 296-300.

18. Li H., Wu B., Mu Ch., Lin W. Concomitant degradation in periodate oxidation of carboxymethyl cellulose // Carbohydrate Polymers. 2011. Vol. 84. Pp. 382-387.

Поступило в редакцию 31 января 2016 г.

После переработки 14 апреля 2016 г. 
Akhmedov O.R. *, Shomurotov Sh.A., Rakhmanova G.G., Turaev A.S. SYNTHESIS AND STUDY OF BIOLOGICAL ACTIVITY OF SULFAMIC POLYSACCHARIDE DERIVATIVES

Institute of Bioorganic Chemistry of the Uzbek Academy of Sciences, ul. M. Ulugbeka, 83, Tashkent, 100125

(Uzbekistan),e-mail: ibchem@uzsci.net

New water-soluble starch derivatives, pectin, and $\mathrm{Na}-\mathrm{CMC}$ containing sulfamic groups were obtained through reacting sulfamic acid with dialdehyde polysaccharide derivatives. The structure and composition of the obtained compounds was studied by IR spectroscopy, elemental (nitrogen, sulfur), and x-ray diffraction analysis.

Sulfamic starch derivatives, pectin, and Na-CMC with different content of sulfamic groups were obtained by varying the concentration of sulfamic acid against dialdehyde polysaccharide derivatives. The optimal ratio which was found is equal to $-\mathrm{CHO}: \mathrm{NH}_{2} \mathrm{SO}_{3} \mathrm{H}=1,0: 2,5$.

The interaction speed of sulfamic acid with dialdehyde starch derivatives, pectin, and Na-CMC was studied.

Study results of the antibacterial and antifungal effect of sulfamic starch derivatives' sodium salts, pectin, and Na-CMC. Biological activity of the obtained compounds was studied at different concentrations such as $10,25,50 \mathrm{mg} / \mathrm{ml}$ disk diffusion method against Gram-positive and Gram-negative bacteria and fungi. It was found that synthesized compounds do not exhibit antifungal activity against Candida albicans. Nevertheless, they have antibacterial activity against Staphylococcus aureus, Staphylococcus epidermidis, Escherichia coli, Proteus vulgaris, Streptococcus faecalis, Streptococcus pyogenes, and Streptococcus faecalis at a concentration of $50 \mathrm{mg} / \mathrm{ml}$.

The dependence of antibacterial action of the sodium salt of sulfamic starch derivatives, pectin, and Na-CMC from concentration is shown.

Direct dependence of the antibacterial activity of drugs was established through the quantitative content of sulfamic groups in polysaccharides. Study presents the results on acute toxicity of sulfamic polysaccharide derivatives. Based on the study results they can be attributed to class V-practically nontoxic substances.

Keywords: Starch, pectin, Na-CMC, periodate oxidation, sulfamic acid, acute toxicity, antibacterial activity.

\section{References}

1. Diatlov V.A., Kruppa I.S., Mamaeva S.A., Kutergina I.Iu., Gumnikova V.I., Grebenova T.A., Kireev V.V. Khimiia prirodnykh soedinenii, 2014, no. 6, pp. 845-849. (in Russ.).

2. Khomiakov K.P., Penezhnik M.A., Virnik A.D., Rogovin Z.A. Vysokomolekuliarnye soedineniia, 1965, vol. 7, no. 6, pp. 1030-1034. (in Russ.).

3. Snezhko V.A., Komar V.P., Khomiakov K.P., Virnik A.D., Zhbankov R.G., Rozenberg G.Ia., Rogovin Z.A. Vysokomolekuliarnye soedineniia, 1974, vol. 16 A, no. 10, pp. 2233-2238. (in Russ.).

4. Shomuratov Sh.A., Murodov E.A., Turaev A.S. Khimiia rastitel'nogo syr'ia, 2006, no. 2, pp. 25-28. (in Russ.).

5. Khomiakov K.P., Virnik A.D., Ushakov S.N., Rogovin Z.A. Vysokomolekuliarnye soedineniia, 1965, vol. 7, no. 6, pp. 1035-1039. (in Russ.).

6. Teviashova A.N., Olsufeva E.N., Preobrazhenskaia M.N., Klesov A.A., Zomer E., Plat D. Bioorganicheskaia khimiia, 2007, vol. 33, no. 1, pp. 148-155. (in Russ.).

7. Liu K., Xu Y., Lin X., Chen L., Huang L., Cao Sh., Li J. Carbohydrate Polymers, 2014, vol. 110, pp. 382-387.

8. Akhmedov O.R., Shomurotov Sh.A., Turaev A.S. Sovremennye aktual'nye problemy estestvennykh nauk. Materialy mezhduna-rodnoi nauchno-prakticheskoi internet-konferentsii. [Current urgent problems of the natural sciences. Proceedings of the International scientific and practical Internet-conference]. Aktobe, Kazakhstan, 2014, vol. 1, pp. 98 101. (in Russ.).

9. Patent 2435785 (RU). 2011. (in Russ.).

10. Guo J., Li X., Mu Ch., Zhang H, Qi P., Li D. Food Hydrocolloids, 2013, vol. 33, pp. 273-279.

11. Ge L., Li X., Zhang R., Yang T., Ye X., Li D., Mu Ch. Food Hydrocolloids, 2015, vol. 51, pp. 129-135.

12. Akhmedov O.R., Shomurotov Sh.A., Turaev A.S. Uzbekskii khimicheskii zhurnal, 2013, no. 1, pp. 30-33. (in Russ.).

13. Nadzhimutdinov Sh., Sarymsakov A.A., Usmanov Kh.U. Cellulose chemistry and technology, 1981, vol. 15, no. 16, pp. 613-628.

14. Tsitovich I.K. Kurs analiticheskoi khimii. [Course of Analytical Chemistry]. Moscow, 1977, p. 346. (in Russ.).

15. Ding W., Zhao P., Li R. Carbohydrate Polymers, 2011, vol. 83, pp. 802-807.

16. Vorob'ev A.A., Krivoshein A.I., Shirobokov V.P. Meditsinskaia i sanitarnaia mikrobiologiia. [Medical and sanitary microbiology]. Moscow, 2003, p. 44. (in Russ.).

17. Yu J., Chang R., Ma X. Carbohydrate Polymers, 2010, vol. 79, pp. 296-300.

18. Li H., Wu B., Mu Ch., Lin W. Carbohydrate Polymers, 2011, vol. 84, pp. 382-387.

Received January 31, 2016

Revised April 14, 2016

\footnotetext{
* Corresponding author.
} 